\title{
The role of biofilm formation in pathogenesis of Helicobacter pylori infections
}

\author{
Rola biofilmu w patogenezie zakażeń Helicobacter pylori
}

\author{
Aldona Bińkowska, Monika Biernat, Irena Duś, Grażyna Gościniak \\ Department of Microbiology, Wroclaw Medical University, Poland
}

Prz Gastroenterol 2013; 8 (1): 27-30

DOI: $10.5114 /$ pg.2013.34179

Key words: biofilm, Helicobacter pylori, infections, gastrointestinal tract.

Słowa kluczowe: biofilm, Helicobacter pylori, zakażenia, przewód pokarmowy.

Address for correspondence: Aldona Bińkowska, Department of Microbiology, Wroclaw Medical University, 4 Chałubińskiego St, 50-368 Wroclaw, Poland, phone: +48 7178412 88, e-mail: aldona.binkowska@gmail.com

\begin{abstract}
The significance of biofilm in pathogenesis of Helicobacter pylori (H. pylori) infections is poorly understood. Biofilm is thought to play a role in transmission of infection to humans, may influence the nature of inflammatory changes in the gastrointestinal tract, and may cause reinfection. In this study, the forms of life of H. pylori, biofilm formation in the environment and human gastrointestinal tract and its impact on the course of infection as well as difficulties in elimination of infections accompanied with biofilm are discussed.
\end{abstract}

\section{Introduction}

The ability of bacteria to form biofilm is a phenomenon known since the times of Van Leeuwenhoek, but biofilm theory in the pathogenesis of infection was not widespread until 1978. In the last few years it has been shown that microorganisms such as staphylococci, enterococci, Gram-negative rods, and Candida spp., which form biofilm, lead to severe nosocomial pneumonia (intubation), urinary tract infections (catheter), suppurative infections, central nervous system infections, and bacterial sepsis.

Biofilm is a heterogeneous layer of cells and a highly organized spatial structure that allows bacteria to coordinate their life processes for protection and survival in the environment [1, 2]. Infections caused by Helicobacter pylori $(H$. pylori) bacilli are among the most common infections in humans throughout the world. In Poland, the incidence of infection in children aged $0-18$ years is about $30.41 \%$, and in people between

\section{Streszczenie}

Znaczenie biofilmu w patogenezie zakażeń pałeczkami Helicobacter pylori (H. pylori) nie jest do końca poznane. Uważa się, że biofilm może odgrywać rolę $w$ transmisji zakażenia tymi drobnoustrojami, a także wpływać na charakter zmian zapalnych w przewodzie pokarmowym człowieka i przyczyniać się do ponownej infekcji. W pracy omówiono formy bytowania $H$. pylori, tworzenie się biofilmu w środowisku zewnętrznym i w przewodzie pokarmowym człowieka, jego wpływ na przebieg zakażenia oraz trudności w eliminacji zakażeń przebiegających z tworzeniem biofilmu.

19 and 29 years of age reaches 70\% [3]. Infection with H. pylori is acquired in early childhood and in the majority of people is asymptomatic. However, approximately in $10 \%$ of infected people morphological changes occur in the gastric mucosa, which lead to the development of stomach ulcers and/or duodenal ulcer, chronic gastritis, and rarely gastric cancer, MALT lymphoma or Ménétrier's disease [4]. In recent years researchers have been interested in the phenomenon of biofilm formation by $H$. pylori. It is believed that the biofilm may play a role in the pathogenesis of infection and transmission of these pathogens, as well as affecting the nature of the inflammation in the human digestive tract.

\section{Forms of Helicobacter pylori bacilli living in different environments}

Helicobacter pylori lives in the digestive tract of human and domestic animals. However, the main reservoir of $H$. pylori is man. The presence of the bacteria has 
been found in dental plaque, saliva, foci of gastric metaplasia, in the duodenum, bile and faeces [5]. There are many observations that the infection is spread by the following ways: oral-oral, faecal-oral, gastro-oral and stomach-stomach route. However, the exact way of transfer of these organisms to humans has not been found. This does not preclude, however, the external environment, and in particular water, as a source of infection. In the spread of infection there are also likely to be important coccoid forms of these microorganisms [6].

Based on studies using electron microscopy, three basic forms of existence of $H$. pylori have been distinguished: a spiral form (culture, virulent, contagious), a coccoid form (non-cultivated, less virulent) and a degenerative coccoid form [6]. Moreover, this bacterium shows the ability to transform from the spiral to the coccoid form, passing through an intermediate U-shaped form [6, 7]. The spiral form has been detected in biopsy specimens of gastric mucosa in patients with duodenal ulcer or chronic gastritis [8]. Under adverse environmental conditions (lack of nutrients, prolonged incubation in vitro) coccoid forms develop, which may be a dormant stage of existence and enable survival in the external environment as well $[6,8]$. Spiral and coccoid forms have almost identical structures, and proteins of the cytoplasm and cell membrane have the characteristic features of Gram-negative bacteria. According to some researchers, these findings indicate that the coccoid form cells remain viable. Degenerative forms in contrast contain degraded DNA, certain degenerated porins and adhesins and disintegrated cell membrane. They are also much larger in size [6].

\section{Environmental biofilm of Helicobacter pylori}

Many studies have shown that $H$. pylori rods are viable in the environment, particularly in water, where they exist in the coccoid form or in the form of bacterial biofilm [6, 7]. The first analyses of biofilm production by these microbes in aquatic environments were conducted in Peru and showed that water coming from the water supply may be a potential source of $H$. pylori infection [9]. Also, Watson et al. [10] studied the presence of these microorganisms in water systems and drinking water supplies in the UK. Despite failed attempts to culture H. pylori from these sites, the research showed the ability of biofilm formation by these microbes on the surface of taps and water pipes. Numerous in vitro studies conducted by other authors have confirmed the complex structure of biofilm formation by $H$. pylori $[11,12]$.

Cellini et al. [7] described a strain of $H$. pylori called MDC1 derived from the environment, which had a very similar genotype to the genotype of strains associated with the development of gastric cancer. MDC1 strain showed increased expression of the gene vacA $\mathrm{s} 1 \mathrm{~m} 1$ that is associated with high levels of vacuolating toxin production and genes for proteins BabA2 and IceA1 that serve as adhesins. The detected strain also has the ability to form a dense, heterogeneous biofilm, in which the dominant forms were coccoids. This discovery proves that $H$. pylori bacilli with increased virulence potential have the ability to survive outside the body of the host, which may have important implications for the spread of infection.

\section{Factors influencing Helicobacter pylori biofilm formation in the gastrointestinal tract}

Biofilm produced by $H$. pylori is formed in a similar manner as in other bacteria. However, specialized virulence factors, which allow $H$. pylori to escape the immune system of the host and colonize the human gastric environment, in particular also facilitate the formation of a biofilm by these microorganisms. These bacilli produce large amounts of extracellular exopolysaccharides (EPS), which protect bacteria against $\mathrm{pH}$ changes, allowing them to process the transmission and colonization [12]. Thanks to matrix composed of exopolysaccharides, biofilm is flexible and very durable [13].

Like other bacteria, $H$. pylori also has a gene luxS whose expression results in the production of autoinductors - particles signalling in the quorum sensing system, which is responsible for communication between the bacteria forming a biofilm. It has been demonstrated that a mutation in the gene luxS, causing a reduction in its expression, causes inhibition of biofilm formation in most bacteria. In contrast, in $\mathrm{H}$. pylori mutation in the gene luxS does not reduce the adhesion properties, and does not affect the formation of aggregates and the development of the spatial structure of the biofilm [11]. Similar observations have been reported in the case of mutation in the cagE gene. This gene encodes a cytoplasmic ATPase, which enables translocation of the CagA protein in the host cell and, consequently, the induction of interleukin 8 (IL-8) secretion by gastric epithelial cells and activation of many intracellular signalling pathways $[11,14]$. The effect of mutations in a cagE gene was double and even a fourfold increase in biofilm formation as compared to wild strains [11].

Besides mobility and chemotaxis, $H$. pylori, by producing the enzyme mucinase, is able to induce degradation of the oligomeric structure of mucin. Microorganisms associate with the mucin component MUC5CA and TFF1 protein, which stimulates the proteolytic activity of mucinase, increasing the fluidity of mucus. This mechanism facilitates the penetration of bacteria through the 
protective layer and determine the tropism of the bacteria to gastric epithelial cells [15]. In vitro studies have investigated the effect of mucin on the adhesion of $H$. pylori to glass surfaces. Mucin affects the growth of planktonic cells in culture, which in turn leads to an increase in the number of free-living cells, but did not inhibit biofilm formation by the bacteria [11].

After entering the lumen of the stomach, bacteria must cope with the acidic gastric $\mathrm{pH}$ and cross the barrier of the mucus layer to reach the epithelial cells of the stomach - the aim of their attack. Movement, chemotaxis, adhesion processes conditioning secretion of adhesion molecules, as well as the ability to produce urease and VacA toxin, are the crucial skills conditioning the survival of $H$. pylori in the infection site [15]. The $H$. pylori cell wall contains lipopolysaccharide (LPS), which can induce a local and systemic inflammatory response in mammalian cells. Despite the low toxicity it has been demonstrated that $H$. pylori LPS has immunomodulatory capacity and activates immune cells to produce proinflammatory cytokines [16]. Lipopolysaccharide disrupting the homeostasis of the stomach environment, inhibiting the synthesis and secretion of mucin and facilitating adhesion contributes to efficient biofilm structures [17].

\section{Role of Helicobacter pylori biofilm in digestive tract disease}

Helicobacter pylori bacilli colonize the gastric mucosa in the antrum, where they adhere to the epithelium, but most bacteria remain in the lumen of the stomach, where they can travel to other parts of the gastrointestinal tract [4]. Microorganisms can also pass into the intestinal lumen and be excreted in the faeces, and in the case of nausea and vomiting they can colonize dental plaque and gingival pockets, creating a biofilm. The presence of $H$. pylori in the oral cavity has been detected in patients with symptomatic and asymptomatic infection in the stomach. In addition, the incidence of bacteria in the oral cavity may be independent of the prevalence of infection in the stomach. Probably multispecies biofilm present in the oral cavity, which included coccoid forms of $H$. pylori, may play a role in the pathogenesis of gastric reinfection [6].

Coticchia et al. [13], analyzing endoscopic biopsies taken from the oesophagus, stomach and duodenum, collected from people with positive (study group) and negative (control group) rapid urease test results, found that $H$. pylori has the ability to form biofilm in vivo. As a result of analysis of the specimens, it was found that the average percentage of surface area covered with a mucosal biofilm in the patients was $97.3 \%$, while in the control group it was only $1.6 \%$. The examined biofilm was characterized by a dense and mature structure over the entire surface, which was not observed in the control group. It is possible that the ability of bacteria to form biofilm structures in the gastrointestinal tract has an important impact on the course, but also on the severity of inflammatory changes in peptic and duodenal ulcer disease [13].

\section{Resistance of biofilm structure to eliminating factors}

The nature of biofilm and its physiology give it an innate resistance to the human immune system cells, antimicrobial agents and disinfectants. The extracellular polymer (EPS) forms a thick layer of polysaccharide which inhibits access of opsonic antibodies to bacterial cells, which impairs the antigen presentation. Extracellular polymer is a diffusion barrier that hinders the penetration of antimicrobial agents into the biofilm, binding and neutralizing them [18].

Microorganisms living in the biofilm have different metabolism and growth. In addition, they have the ability to communicate using chemical signals, providing genetic information and synchronizing their defensive actions [19]. The presence of surviving cells showing resistance phenotype increases the probability of failure of antibiotic therapy [18]. Bacterial cells forming the structure of the biofilm live in close proximity, allowing them to more easily communicate and exchange genes present on plasmids [19]. Increasing the concentration of enzymes secreted by the bacteria in the biofilm results in the inactivation of antibiotics. Furthermore, in different parts of the biofilm there are significant differences in osmotic pressure, as well as availability of various nutrients, and variable density of the cells [18].

\section{Resistance of Helicobacter pylori biofilm to drugs}

Biofilm formed by $H$. pylori protects against the human immune system and facilitates the survival of these bacteria in the difficult environment of the gastric mucosa. It seems that it also provides high resistance to antimicrobial agents such as antibiotics and disinfectants [12].

In the treatment of infections caused by $H$. pylori a three-component therapy is indicated, including receiving two of three antibiotics (amoxicillin and clarithromycin or metronidazole) and a proton pump inhibitor (PPI) (omeprazole, pantoprazole, lansoprazole) $[20,21]$. However, in $10 \%$ to $20 \%$ of cases this therapy is ineffective. The main cause of treatment failure of $H$. pylori infection is primary or acquired resistance of the bacteria to one of the used antibiotics [22]. There are 
reports that $H$. pylori eradication failure is related not only to the mechanisms of resistance to medication, but also to other factors, both from the bacteria and from the host. The number of bacterial cells in the gastric mucosa is very high and causes the so-called inoculum effect. A large part of the population of bacteria is associated with the mucosa and forms a biofilm on its surface, and a small amount of bacterial cells is localized intracellularly and is not sensitive to the antibiotics. The intracellular $H$. pylori cell population is not active and is able to survive in this form until the treatment is stopped. This population of cells, and the phenomenon of biofilm formation itself, are probably responsible for the occurrence of re-infection [23]. In the case of therapeutic failure, different treatment regimens, new antibiotics, variable doses and longer duration of therapy have been used $[20,21]$. There are few studies on the effects of antibiotics on biofilm eradication of $H$. pylori. It appears that the most effective are clarithromycin and bismuth salts [12]. Cammarota et al. [24] found that $\mathrm{N}$-acetylcysteine given before antibiotic treatment significantly reduces biofilm formation, and thus contributes to a better therapeutic effect against infections with resistant strains of $H$. pylori.

The importance of biofilm in the pathogenesis of $H$. pylori infection is not fully understood. Many researchers suggest that it may be responsible for the failure of $\mathrm{H}$. pylori eradication and contribute to the survival of microorganisms in the focal infection, leading to reinfection. Therefore, it is important to continue research to understand the process of biofilm formation by these organisms, as well as the effects of various substances on the process and structure of a mature biofilm. It is also important to know how to inhibit biofilm formation, weakening the structures of mature and effective eradication of infections involving biofilm.

\section{References}

1. Donlan RM, Costerton JW. Biofilms-survival mechanisms of clinically relevant microorganisms. Clin Microbiol Rev 2002; 15: 167-93.

2. Davey ME, O'toole GA. Microbial biofilms: from ecology to molecular genetics. Microbiol Mol Bio Rev 2000; 64: 847-67.

3. Iwańczak F, Maciorkowska E, Kaczmarski M, et al. Epidemiological studies of frequency of Helicobacter pylori infection in children in Poland. Ped Wsp 2004; 6: 345-50.

4. Correa P, Piazuelo MB. Natural history of Helicobacter pylori infection. Dig Liver Dis 2008; 40: 490-6.

5. Bruce MG, Maaroos HI. Epidemiology of Helicobacter pylori infection. Helicobacter 2008; 13: 1-6.

6. Andersen LP, Rasmussen L. Helicobacter pylori - coccoid forms and biofilm formation. FEMS Immunol Med Microbiol 2009; 56: 1-4.
7. Cellini L, Grande R, Di Campli E, et al. Characterization of an Helicobacter pylori environmental strain. J Appl Microbiol 2008; 105: 761-9.

8. Azevedo NF, Pacheco AP, Keevil CW, et al. Adhesion of water stressed Helicobacter pylori to abiotic surfaces. J Appl Microbiol 2006; 101: 718-24.

9. Hulten K, Han SW, Enroth $\mathrm{H}$, et al. Helicobacter pylori in the drinking water in Peru. Gastroenterology 1996; 110: 1031-5.

10. Watson CL, Owen RJ, Said B, et al. Detection of Helicobacter pylori by PCR but not culture in water and biofilm samples from drinking water distribution systems in England. J Appl Microbiol 2004; 97: 690-8

11. Cole SP, Harwood J, Lee R, et al. Characterization of monospecies biofilm formation by Helicobacter pylori. J Bacteriol 2004; 186: 3124-32.

12. Stark DG, Gerwig GJ, Pitman RS, et al. Biofilm formation by Helicobacter pylori. Lett Appl Microbiol 1999; 28: 121-6.

13. Coticchia JM, Sugawa C, Tran VR, et al. Presence and density of Helicobacter pylori biofilms in human gastric mucosa in patients with peptic ulcer disease. J Gastrointest Surg 2006; 10: 883-9.

14. Saha A, Hammond CE, Beeson C, et al. Helicobacter pylori represses proton pump expression and inhibits acid secretion in human gastric mucosa. Gut 2010; 59: 874-81.

15. Kaklikkaya N, Cubukcu K, Aydin F, et al. Significance of cagA status and vacA subtypes of $\mathrm{H}$. pylori in determining gastric histopathology: virulence markers of $\mathrm{H}$. pylori and histopathology. J Gastroenterol Hepatol 2006; 21: 1042-7.

16. O'Keffe J, Moran AP. Convential, regulatory and unconvential $T$ cells in the immunologic response to Helicobacter pylori. Helicobacter 2008; 13: 1-19.

17. Slomiany BL, Slomiany A. Interference by leptin with Helicobacter pylori lipopolysaccharide-induced cytosolic phospholipase A2 activation in gastric mucosal cells. J Physiol Pharmacol 2007; 58: 117-30.

18. Różalska B, Sadowska B, Walencka E. Detection and perspectives for anti-biofilm therapy in medicine. Zakażenia 2010; 1: 13-21.

19. Fux CA, Stoodley P, Hall-Stoodlay L. Bacterial biofilms: a diagnostic and therapeutic challenge. Expert Rev Anti Infec Ther 2003; 1: 667-83.

20. Malfertheiner P, Megraud F, O'Morain C, et al. Current concepts in the management of Helicobacter pylori infection: the Maastricht III Consensus Report. Gut 2007; 56: 772-81.

21. Dzieniszewski J, Jarosz M; Working Group PTG - E on Helicobacter pylori infection. Consensus of the Polish Society of Gastroenterology Helicobacter pylori Working Group on diagnostic and therapeutic approaches for the Helicobacter pylori infection 2008. Gastroenterol Pol 2008; 15: 323-31.

22. Megraud F. Helicobacter pylori and antibiotic resistance. Gut 2007; 56: 1502.

23. Carron MA, Tran VR, Sugawa C, et al. Identyfication of Helicobacter pylori biofilms in human gastric mucosa. J Gastrointest Surg 2006; 10: 712-7.

24. Cammarota G, Branca G, Ardito F, et al. Biofilm demolition and antibiotic treatment to eradicate resistant Helicobacter pylori: a clinical trial. Clin Gastroenterol Hepatol 2010; 8: 817-20. 